\title{
Sap Transmission and Host Range Study of Soybean Mosaic Virus in Soybean
}

\author{
M. Hajong ${ }^{1 *}$, P.C. Atram ${ }^{1,2}$ and S.S. Mane ${ }^{1}$ \\ ${ }^{1}$ Department of Plant Pathology, Post Graduate Institute, Dr. Panjabrao Deshmukh Krishi \\ Vidyapeeth, Akola-444104, Maharashtra, India \\ ${ }^{2}$ AICRP on Agroforestry, College of Agriculture, Nagpur, Maharashtra, India
}

*Corresponding author

\section{A B S T R A C T}

\section{Keywords}

Glycine max, Host

range, Sap

inoculation and

Soybean mosaic

virus.

Article Info

Accepted:

06 July 2018

Available Online:

10 August 2018
Among the viral diseases, Soybean mosaic virus (SMV) is believed to have economic significance in India. Soybean mosaic is found in almost all soybean growing areas of India but usually in low to moderate intensity. Soybean plants infected with SMV were collected from different locations of Akola, Maharashtra, India. Symptoms of SMV in soybean include mosaic, rolling and puckering of foliage and chlorosis of older leaves with stunted growth. The SMV was readily sap transmissible to test plants. The virus inoculums was prepared in $0.5 \mathrm{M}$ Potassium phosphate buffer ( $\mathrm{pH}$ 6.5) and inoculated into test plants (i.e., soybean and cowpea). Inoculated plants were observed 2-3 days after inoculation (DAI) for the development of symptoms. Symptoms like light and dark green patches on upper leaves and initial chlorotic spots were observed. Host range study was done from sap inoculation to understand different host of the SMV.

\section{Introduction}

In India, soybean (Glycine max (L.) Merrill) has been the number one oilseed crop in terms of both area and production since 2005. In India, soybean is mainly grown in the states of Madhya Pradesh, Maharashtra, Rajasthan, Karnataka, Andhra Pradesh, Chattisgarh, Nagaland and Gujarat as a rainfed crop during the rainy (Kharif) season.

Soybean is severely attacked about half a dozen of major diseases, a dozen of insect pest and several major weeds. Yield losses due to individual disease/insect/weed species ranges from 20 to 100 per cent (Anonymous, 2014).

SMV is the most prevalent virus and is recognized as the most serious, long-standing problem in many soybean producing areas in the world (Wang, 2009). The disease caused by SMV was first documented in the USA in 1915 by Clinton (1916) and SMV was named by Gardner and Kendrick (1921). Yield losses by SMV usually range from 8 to $50 \%$ under natural field conditions (Hill, 1999 and Arif and Hassan, 2000) and reach up to $100 \%$ in severe outbreaks (Liao et al., 2002). SMV was 
mechanically transmitted to test plants when the inoculum was prepared in $0.5 \mathrm{M}$ phosphate buffer (pH 7.0) (Balgude et al., 2012). Apart from mechanical inoculation, SMV is transmitted also by seed transmission and aphid vectors (Bashar, 2015). Since no cultivars have adequate resistance to this virus, yield losses have been a serious problem in India. In the present investigation main focused was on the host range study of SMV. By understanding the host range, one can go for management practices and suppress SMV incidence at minimum level in the field.

\section{Materials and Methods}

\section{Raising of test plants/seedlings}

Seeds of different test plants viz soybean (JS 335) and cowpea (pusa kamal) and for host range study papaya, greengram, blackgram, tomato, chilli, sunflower, tobacco, cauliflower, cabbage, dhatura and chenopodium were used for raising of test plants.Test plants were raised in insect proof cage house in small pots (6" diameter) containing sterilized mixture of soil+sand +FYM (2:1:1). One seedling was placed in each pot.

\section{Collection of mosaic infected soybean plants}

The soybean plants showing symptoms of mosaic or dark green patches on leaves were collected from the Dept. of Plant Pathology, Botany and Entomology fields of Dr. Panjabrao Deshmukh Krishi Vidyapeeth (Dr.PDKV) and different regions of Akola (Maharashtra). Samples were kept at $-80^{\circ} \mathrm{C}$ in plastic bags with labels indicating the nature of the crop and the location from where it was collected.

\section{Characterization of SMV by sap inoculation}

The isolated virus were used to maintain on different test plants by mechanical inoculation using $0.5 \mathrm{M}$ Potassium phosphate buffer $(\mathrm{pH}$ 6.5). The sap was then clarified by straining two fold muslin cloth and inoculated to the first true leaf of the seedlings by previously dusted carborandum 600 mesh as a abrassive. Immediately after inoculation,the leaves were washed thoroughly with tap water to remove excess of inoculum and abrassive. For each test plant, uninoculated seedlings were also maintain to compare the symptom i.e.control. All the inoculated plants were maintained in an insect proof cage house with proper labelling till the development of symptoms. The method of sap inoculation was used throughout the course of investigation for transmission of virus into the healthy plants and for the development of proper diseased symptoms.

\section{Host range and symptomology study}

The plant species belonging to the families Solanaceae, Cucurbitaceae, Amaranthaceae, Compositae, Leguminosae, Cruciferacea, and Malvaceae were mechanically inoculated to know the host range of SMV. The plants raised under insect proof condition were inoculated at the appropriate growth stage by sap inoculation.

\section{Results and Discussion}

\section{Symptoms of SMV under field condition}

Symptoms of SMV observed under natural condition were stunted growth, fewer pods that are sometimes dwarfed and flattened, without hairs and seeds. Trifoliate leaves exhibited mosaic of light and dark green areas that may become blistered or raised, particularly along the main veins (Fig.1a \& b).

\section{Sap transmission}

Sap inoculated seedlings were observed regularly for symptom expression. 
Table.1 Sap transmission of the causal virus for identification of test plants

\begin{tabular}{|c|c|c|c|c|c|c|}
\hline \multirow{2}{*}{$\begin{array}{l}\text { Sl. } \\
\text { No. }\end{array}$} & \multirow[t]{2}{*}{ Test plants } & \multirow[t]{2}{*}{ Cultivar } & \multicolumn{2}{|c|}{ No. of plants } & \multirow{2}{*}{$\begin{array}{c}\text { Transmission } \\
(\%)\end{array}$} & \multirow{2}{*}{$\begin{array}{l}\text { Time taken } \\
\text { for } \\
\text { symptom } \\
\text { expression }\end{array}$} \\
\hline & & & Inoculated & Infected & & \\
\hline 1 & $\begin{array}{l}\text { Soybean (Glycine } \\
\text { max) }\end{array}$ & JJ-335 & 5 & 5 & 100 & 15 days \\
\hline 2 & $\begin{array}{l}\text { Cowpea } \\
\text { unguiculata) }\end{array}$ & $\begin{array}{l}\text { Pusa } \\
\text { Kamal }\end{array}$ & 5 & 3 & 60 & 25 days \\
\hline
\end{tabular}

Table.2 Reactions of different hosts against viruses associated with floral bud distortion of soybean

\begin{tabular}{|c|c|c|c|c|c|c|}
\hline \multirow{2}{*}{$\begin{array}{l}\text { Sl. } \\
\text { No. }\end{array}$} & \multirow{2}{*}{$\begin{array}{l}\text { Name of the host with } \\
\text { family }\end{array}$} & \multicolumn{2}{|c|}{ No. of plants } & \multirow{2}{*}{$\begin{array}{c}\text { Per cent } \\
\text { transmission } \\
(\%)\end{array}$} & \multirow{2}{*}{$\begin{array}{c}\text { Incubation } \\
\text { period } \\
\text { (Days) }\end{array}$} & \multirow[t]{2}{*}{ Symptoms } \\
\hline & & Inoculat-ed & Infected & & & \\
\hline 1 & Leguminoseae & & & & & \\
\hline a) & Glycine max & 5 & 5 & 100 & 15 & $\begin{array}{l}\text { Chlorotic spots, mosaic } \\
\text { and puckering of foliage }\end{array}$ \\
\hline b) & Vigna unguiculata & 5 & 3 & 60 & 25 & Chlorotic spots \\
\hline c) & Dolichos lablab & 5 & - & - & - & No symptoms \\
\hline d) & Capsicum annum & 5 & - & - & - & No symptoms \\
\hline 2 & Solanaceae & & & & & \\
\hline a) & Datura stramonium & 5 & 2 & 40 & 15 & $\begin{array}{l}\text { Chlorotic spots and vein } \\
\text { clearing }\end{array}$ \\
\hline b) & $\begin{array}{l}\text { Parthenium } \\
\text { histerophorus }\end{array}$ & 5 & 3 & 60 & 15 & Initial chlorotic spots \\
\hline c) & $\begin{array}{l}\text { Lycopersicon } \\
\text { esculentum }\end{array}$ & 5 & 3 & 60 & 20 & Chlorotic spots \\
\hline d) & Nicotiana tabacum & 5 & - & - & - & No symptoms \\
\hline 3 & Cucurbitaceae & & & & & \\
\hline a) & Cucumis sativus & 5 & 1 & 20 & 20 & Mild chlorotic spots \\
\hline b) & Cucumis melo & 5 & - & - & - & No symptoms \\
\hline c) & Citrullus fistolusum & 5 & - & - & - & No symptoms \\
\hline d) & Citrullus lunatus & 5 & - & - & - & No symptoms \\
\hline 4 & Caricaceae & & & & & \\
\hline a) & Carica papaya & 5 & 2 & 40 & 25 & $\begin{array}{l}\text { Mosaic and leaf } \\
\text { puckering }\end{array}$ \\
\hline 5. & $\begin{array}{l}\text { Asteraceae/Composit } \\
\text { ae }\end{array}$ & & & & & \\
\hline a) & Helianthus annииs & 5 & - & - & - & No symptoms \\
\hline 6 & Malvaceae & & & & & \\
\hline a) & Gossypium hirsutum & 5 & - & - & - & No symptoms \\
\hline 7. & Crucifereae & & & & & \\
\hline a) & $\begin{array}{l}\text { Brassica oleraceae } \\
\text { var.capitata }\end{array}$ & 5 & - & - & - & No symptoms \\
\hline b) & $\begin{array}{l}\text { Brassica oleraceae } \\
\text { var.botrytis }\end{array}$ & 5 & - & - & - & No symptoms \\
\hline 8. & Amaranthaceae & & & & & \\
\hline a) & $\begin{array}{l}\text { Amaranthus } \\
\text { paniculatus }\end{array}$ & 5 & - & - & - & No symptoms \\
\hline
\end{tabular}


Fig.1 Symptoms of SMV, a: field view of SMV of soybean, b: leaf puckering with dark green foliage
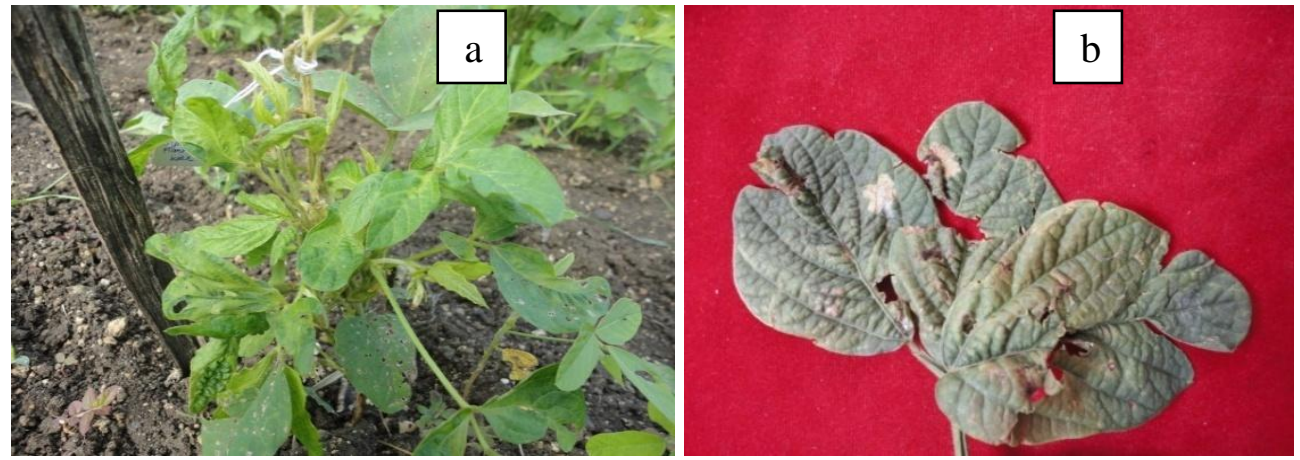

Fig.2 Reaction of different hosts against SMV, a: Mosaic and leaf puckered on soybean foliage; b: Initial chlorotic spots on cowpea leaves; c: Mild chlorotic spots on cucumber foliage and d: Chlorotic spots on dhatura leaves
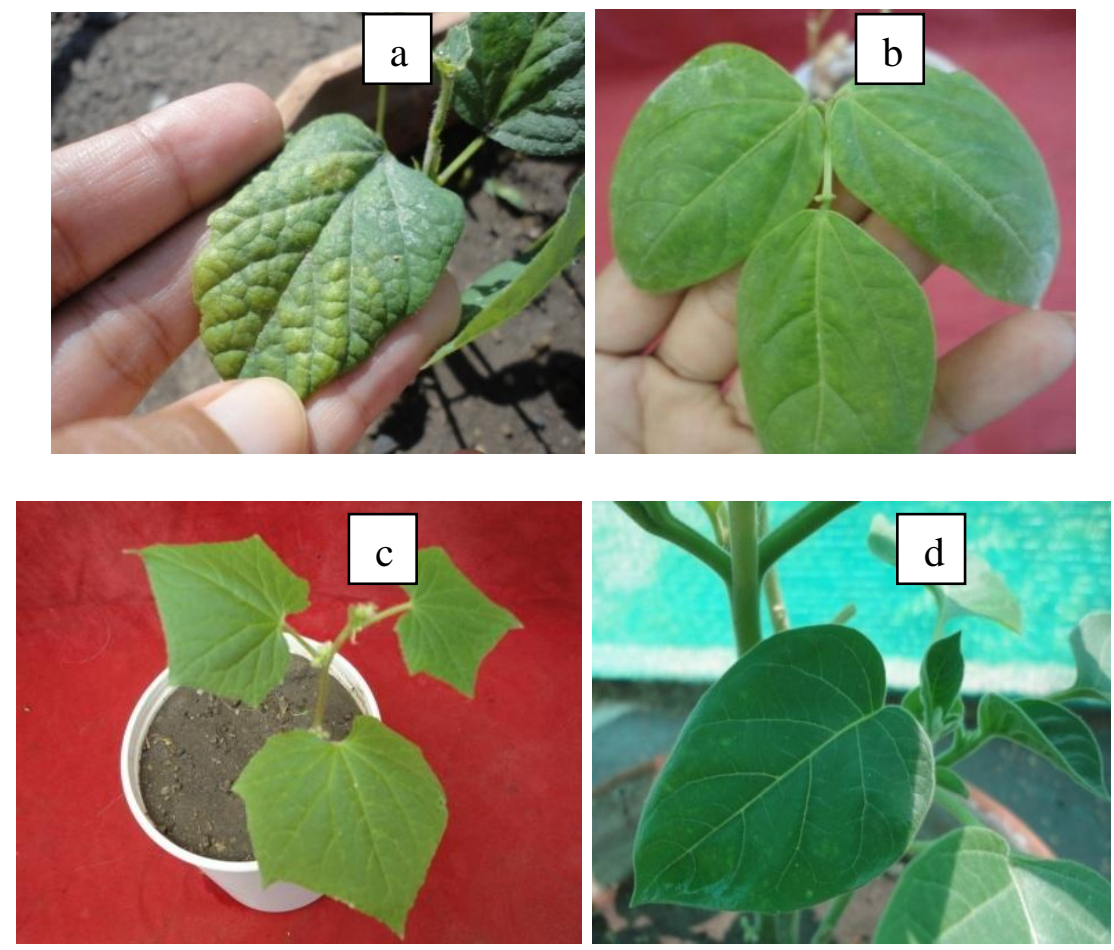

The infected soybean seedlings developed mosaic, distorted leaf and chlorotic symptoms after inoculation within 15-20 days which were identical to the symptoms observed in the field. In cowpea it was difficult to produce any symptoms only mild chlorotic spots developed on leaves. After 15 days soybean showed mosaic and leaf puckering symptoms which were identical to the symptoms observed in the field. The results presented in Table 1, clearly revealed that the virus was not readily sap transmissible to cowpea as only 3 plants out of 5 developed chlorotic spot with transmission rate of 60 per cent and it took 25 days for symptom expression. Whereas soybean showed highest transmission of 100 per cent and took only 15 days for symptom expression. Earlier reported 
that inoculum applied to both unifoliate and first trifoliate leaves of soybean seedlings pre dusted with carborundum produced mosaic symptoms (Zheng et al., 2005).

\section{Host range study}

In comparison with other potyviruses, SMV has a relatively narrow host range. It infected four plant families, i.e., Leguminosae, Solanaceae, Cucurbitacea and Caricacea, but mostly the Leguminosae including soybean (Galvez, 1963 and Hill, 1999). Eighteen plant species belonging to eight families were mechanically inoculated with standard extract of SMV as described under "Materials and Methods". In host range studies, the infection of virus under study was observed on seven species belonging to the families of Solanaceae, Cucurbitaceae, Leguminosae and Caricaceae (Fig. 2). Rest of plant species belonging to three families'viz., Crucifereae, Amarantheceae and Malvaceae were found non hosts to the infection by SMV (Table 2). Earlier reported legumenous as a host of SMV (Walters, 1963).

Among the different hosts, soybean recorded 100 per cent transmission and expressed the symptoms like mosaic, distorted leaf, and chlorotic spots which took 15 days for symptom expression (Fig. 2a). On cowpea, the virus produced necrotic spots and chlorotic spots which took 20 days for the expression of symptoms from the date of inoculation and recorded 60 per cent transmission (Fig. 2b). Cucumber expressed mild chlorotic spots and recorded 20 per cent transmission in 30 DAI (Fig. 2c). Parthenium histerophorus recorded 10 per cent transmission and showed chlorotic and mosaic symptoms which took 20 days for the expression of symptoms after inoculation (Fig. 2d). Earlier reported that SMV was readily sap transmissible to test plants when the inoculum was prepared in $0.1 \mathrm{M}$ Phosphate buffer ( $\mathrm{pH}$ 7.0) and produced systematic symptoms like light and dark green patches on upper leaves of soybean (Boss, 1972; Patil and Byadgi, 2005 and $\mathrm{Lu}, 2008$ ).

\section{Acknowledgements}

We thank Dr. S. S. Mane, Head, Dept. of Plant Pathology, Dr. Panjabrao Deshmukh Krishi Vidyapeeth, Akola (Maharashtra) for providing necessary facilities and supporting this research throughout the course of investigation.

\section{References}

Anonymous. 2014. Integrated pest management package for soybean. Ministry of Agriculture, Department of Agriculture \& Cooperation, Directorate of Plant Protection, Quarantine \& Storage, Haryana121001.

Arif, M. and Hassan S. 2000. Occurrence and Distribution of Soybean Potyvirus in Soybean Crop of North-West Frontier Province, Pakistan and Characterization of Prevalent Isolates. Pak. J. Biol. Sci. 3(12):2126-2130.

Balgude, Y.S., Sawant, D.M. and Gaikwad, A.P. 2012. Transmission studies of Soybean mosaic virus. J. Pl. Dis. Sci. 7(1):52-54.

Bashar, T. 2015. Characterization of Seed Transmission of Soybean Mosaic Virus in Soybean. Ontario: The University of Western Ontario, London.

Boss, L. 1972. Soybean mosaic virus: Description of Plant Viruses, No. 93. Common wealth Mycological Institute and Association of Applied Biologists, Kew, England.

Clinton, G.P. 1916. Reports of the botanist for 1915: soybeans. Annual Report, Connecticut Agricultural Experiment 
Station 1915, Pp. 446.

Galvez, G.E. 1963. Host range, purification, and electron microscopy of Soybean mosaic virus. Phytopathology. 53: 388-393.

Gardner, M.W. and Kendrick, J.B. 1921. Soybean mosaic virus. J. Agric. Res. 22:111-114.

Hill, J.H. 1999. Soybean Mosaic Virus. In:"Compendium of Soybean Diseases". 4th Ed., Hartman, G.L., Sinclair, J.B. and Rupe, J.C. (Eds.). The American Phytopathological Society, St. Paul, Minnesota. Pp. 7071.

Liao, L., Chen, P., Buss, G.R., Yang, Q. and Tolin, S.A. 2002. Inheritance and allelism of resistance to Soybean mosaic virus in Zao18 soybean from China. J. Hered. 93(6):447-452. canker in Iowa soybean fields. Iowa: Iowa State University.

Patil, R.G. and Byadgi, A.S. 2005. Transmission Studies of Soybean Mosaic Virus. Karnataka J. Agric. Sci.18: 52-54.

Walters, H.J. 1963. Leguminous hosts of Soybean mosaic virus. Pl. Dis. Reptr. 47:726-728.

Wang, A. 2009. Soybean mosaic virus: research progress and future perspectives. Proceedings of World Soybean Research Conference VIII (www.wsrc2009.cn), Beijing, China.

Zheng, C., Chen, P. and Gergerich, R. 2005. "Characterization of resistance to Soybean mosaic virus in diverse soybean germplasm", Crop Sci. 45(6):2503.

$\mathrm{Lu}, \mathrm{X}$. 2008. Soybean mosaic and stem

\section{How to cite this article:}

Hajong, M., Atram, P.C. and Mane, S.S. 2018. Sap Transmission and Host Range Study of Soybean Mosaic Virus in Soybean. Int.J.Curr.Microbiol.App.Sci. 7(08): 795-800. doi: https://doi.org/10.20546/ijcmas.2018.708.089 